required to place the resulting cell lines in the new bank; other UK funding agencies are expected to introduce similar guidelines. Providing the cells meet strict quality-control criteria, they will then be frozen, stored and made available to anyone who wants them for projects approved by an advisory committee.

At first, only groups in Britain will be eligible to apply, but Radda says that the MRC "in principle" would be willing to make them available to overseas groups.

The bank's location has yet to be determined, although Radda says it will not be at a university, a commercial organization or an MRC research institute, as the MRC wants to avoid a situation in which researchers involved in stem-cell research have a say in decisions about who should be supplied with the cells. A decision on location will be made in July, the MRC says.

The ease with which UK researchers will be able to obtain identical cell lines from the bank will help different groups to compare their results, says Richard Gardner, an embryologist at the University of Oxford and chairman of the Royal Society working group on stem-cell research.

Dozens of embryonic stem-cell lines have already been derived worldwide, but Gardner says their quality depends on the conditions under which they were derived - which were highly variable. To provide the best research resource, he suggests, "one essentially needs to start again under very carefully defined conditions"

\title{
White House sets three-point performance plan for science
}

\section{Geoff Brumfiel, Washington}

The White House Office of Management and Budget $(\mathrm{OMB})$ has unveiled its longawaited criteria for evaluating basic research supported by the US government.

Research organizations had worried that the criteria would force agencies to quantify the output of basic research programmes and so would damage high-risk projects (see Nature 413, 5; 2001).

At a meeting at the National Academy of Sciences in Washington on 27 February, OMB officials said that basic research will be measured by three criteria: the quality of the research, its relevance to the funding agency, and its performance based on defined goals and measures.

They added that research programmes should be reviewed every three to five years, and that each agency should set appropriate standards against which its overall research performance can be assessed annually. These measures have yet to be set, and it remains unclear how they will influence agencies' future budgets.

Mitch Daniels, director of the OMB, told the meeting that he was strongly committed to the criteria for basic science. "Even in this most speculative area of government investment, our decisions cannot be immune from standards and quality," he said.

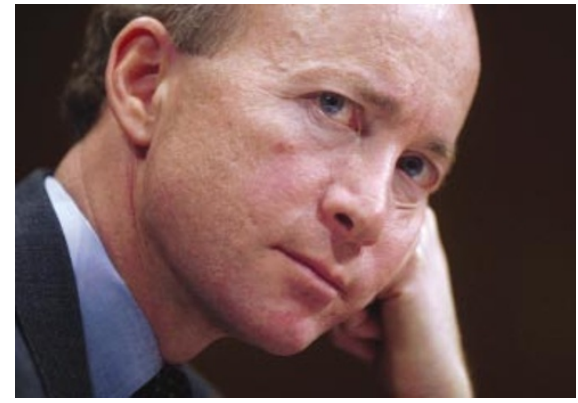

Setting standards: Mitch Daniels is a keen advocate of performance criteria for research.

The meeting did manage to provide some assurance that the process will be managed carefully. "The nervousness people had was that this was some kind of ideological juggernaut," says David Goldston, chief of staff for the science committee in the House of Representatives. "One of the things the OMB did at the meeting was to put that to rest."

But concerns remain. Mildred Dresselhaus, a professor of electrical engineering at the Massachussetts Institute of Technology, warned the meeting that the OMB's calls for regular reports might hurt areas of research that flounder for years before succeeding. "How will we incorporate failure into the criteria?" she asked.

www7.nationalacademies.org/gpra/index.htm!

\section{Stem-cell reverse angers Australian biologists}

Carina Dennis, Sydney

Hints that the Australian government is planning a national ban on the generation of new human embryonic stem-cell lines have drawn fire from biologists and their backers in some of the nation's state governments.

Kevin Andrews, the minister for ageing who is responsible for stem-cell research and

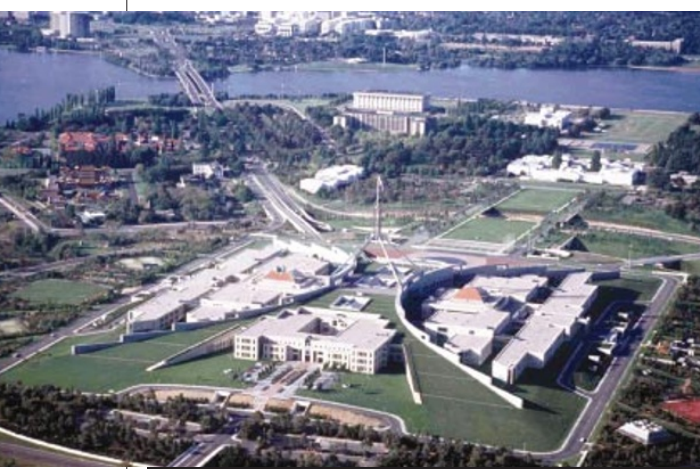

The Australian parliament in Canberra could clash with state governments over biology rules. cloning policy - has given the cabinet a set of proposals which, according to reliable reports, include a ban on the use of human embryos to extract new stem-cell lines.

Andrews has refused to comment on his submission, but has made his opposition to embryo research clear in the past.

Although the government has not finalized its position, supporters of the research are angered by what they see as an attempt to overturn the findings of a twoyear parliamentary inquiry into cloning and stem-cell research, completed last September. The inquiry committee - which Andrews chaired - was unanimous on all issues except the use of discarded embryos in stemcell research, which was approved by a majority. Andrews was one of the minority opposed to such work.

Martin Pera, of the Monash Institute of Reproduction and Development, Melbourne, whose group was one of the first to isolate human embryonic stem-cell lines, argues that additional lines are crucial to offer more options to researchers, and to ensure that genetically diverse lines are available for clinical application.

Robert Jansen, a professor at the University of Sydney and head of Sydney IVF, an in-vitro fertilization clinic, says that restrictive laws in stem-cell research "will put Australia into a backwater" and force researchers abroad.

Under the Australian constitution, health-related matters normally fall under the jurisdiction of the states, not the federal government. The questions of whether federal or state governments will legislate, and of which stem-cell research and cloning technologies should be permitted, will be discussed at the next Council of Australian Governments' meeting in April.

The federal government and the states several of which are governed by the opposition Labor Party - look set to clash on the issue, probably delaying implementation of the agreement reached last year to establish nationally consistent rules by June. 